\title{
Sensitivity Improvement of Odor Sensing System Using Ball SAW Devices
}

\author{
Masaaki Sekine Student Member (Tokyo Institute of technology, sekine.m.ad@m.titech.ac.jp) \\ Bart Wyszynski Non-member (Tokyo Institute of technology, bart@m.titech.ac.jp) \\ Takamichi Nakamoto Member (Tokyo Institute of technology, nakamoto@m.titech.ac.jp) \\ Noritaka NakasoＮon-member（Toppan Printing Company, noritaka.nakaso@toppan.co.jp) \\ Kazuhiro NoguchiＮon-member (Toppan Printing Company, kazuhiro.noguchi@toppan.co.jp)
}

Keywords : odor sensor, ball SAW device, AC electrospray, sensing film

In this report, we improve a sensitivity of odor sensing system using ball SAW devices. Although, we reported the three-flavor identification using four ball SAW devices with different sensing films, the concentrations of the fruits flavors had to be high in the previous study. Thus several optimizations were performed here. First, we optimized the coating parameters of AC electrospray method. Second, we optimized sensing film thickness. Thirdly, we used Savitzky-Golay filter for smoothing response waveforms.

Fig.1 shows the experimental setup for low concentration odor. When VOCs are introduced to the sensor cell by the pump, SAW phase shift is measured using a digital quadrature detector (QOD). The measurement interval of the phase value is $1 \mathrm{~ms}$ and it is possible to average 256 measurements over $0.256 \mathrm{~s}$. The concentrations of VOCs are measured using the Photo Ionization detector (PID) before experiments.

Fig. 2 shows the second derivative waveform of response to 90ppb butanol, which is below human threshold, after filtering by Savitzky-Golay filter for combining second-order differentiation with smoothing. After compensation, it is easy to detect adsorption and desorption points.

Fig.3 shows the comparison of ball SAW with QCM sensor



Fig. 1. Experimental setup for low concentration odor response speed the sensor response speeds to butanol of 900ppm.Although it takes 60s to saturate the QCM response, it takes only about $10 \mathrm{~s}$ to saturate the Ball SAW device. The smell sample used the butanol of $900 \mathrm{ppm}$. Thus the response speed of Ball SAW is several times faster than that of QCM.

After the improvement, we could detect butanol of $90 \mathrm{ppb}$ below human threshold. Finally we found that the response speed of the ball SAW device is superior to that of QCM with comparable sensitivity.

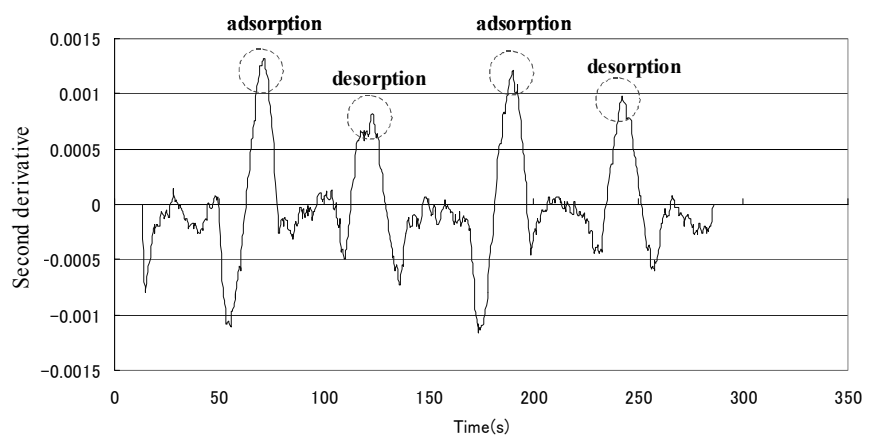

Fig. 2. Waveforms of response to 90ppb butanol after compensation

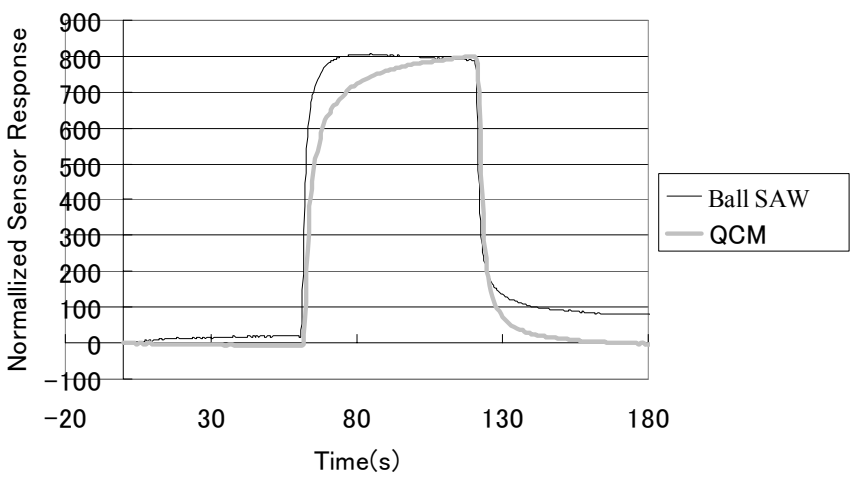

Fig. 3. Comparison of ball SAW with QCM sensor response speed (Sample: butanol 900ppm) 


\section{ボール SAW デバイスを用いた匂いセンサの 感度向上に関寸る研究}

$\begin{array}{llll}\text { 学生員 } & \text { 関根 } & \text { 正顕* } & \text { 非会員 Bartosz Wyszynski* } \\ \text { 正 員 } & \text { 中本 } & \text { 高道* } & \text { 非会員 中兽 教尊** } \\ \text { 非会員 野口 } & \text { 和洋** } & & \end{array}$

\section{Sensitivity Improvement of Odor Sensing System Using Ball SAW Devices \\ Masaaki Sekine, Student Member, Bartosz Wyszynski, Non-member, Takamichi Nakamoto, Member, \\ Noritaka Nakaso, Non-member, Kazuhiro Noguchi, Non-member}

In this report, we improve a sensitivity of odor sensing system using ball SAW devices. Although, we reported the three-flavor identification using four ball SAW devices with different sensing films, the concentrations of the fruits flavors had to be high in the previous study. Thus several optimizations were performed here. First, we optimized the coating parameters of AC electrospray method. Second, we optimized sensing film thickness. Thirdly, we used Savitzky-Golay filter for smoothing response waveforms. After the improvement, we could detect butanol of 90ppb below human threshold. Finally we found that the response speed of ball SAW devices are superior to that of QCM with comparable sensitivity.

キーワード : 匂いセンサ, ボール SAW デバイス, ACエレクトロスプレイ法, 感応膜

Keywords : odor sensor, ball SAW device, AC electrospray, sensing film

\section{1. はじめに}

匂いセンサは，食品，飲料，化粧品，環境計測等多くの 分野で必要とされている(1)。匂いセンサでは特性の異なる複 数のセンサの応答パターンをパターン認識して，匂いの識 別を行う。匂いセンサのセンサ素子には，水晶振動子ガス センサ, SAW（Surface Acoustic Wave：弾性表面波）ガスセ ンサ，半導体ガスセンサ等が用いられている。我々は水晶 振動子（QCM）ガスセンサを中心に研究を行ってきたが匂 いセンサで必要になる集積化と高感度化の可能性があるボー ル SAW デバイス ${ }^{(2)}$ こ注目することにした。

ボール SAW デバイスは压電体球面の上に SAW デバイス を形成したもので，SAW を多重周回させることによりセン シングを行う伝搬経路を長く出来る特長がある(3)(4)。伝搬経 路が長いにもかかわらず同じところを繰り返し周回するた めに，素子自体は小型である。ボール SAW デバイスはこれ

* 東京工業大学大学院 理工学研究科 電子物理工学専攻 干152-8552 東京都目黒区大岡山 2-12-1

Department of Physical Electronics, Tokyo Institute of Technology 2-12-1 Ohokayama, Meguroku, Tokyo 152-8552

** 凸版印刷（株） 総合研究所 次世代商品研究所

T345-8508 埼玉県北葛飾郡杉戸町高野台南 4-2-3 Advanced Research Laboratory, Technical Research Institute, Toppan printing corporation

4-2-3 Takanodaiminami, Sugito-machi, Saitama 345-8508
までに水素ガスセンサに応用されてきており ${ }^{(5)}$, また以前に 我々は匂いセンサ応用に成功し，3 種類の匂いの識別に成功 している(6)。しかし, この研究では濃度の高い匂いに対する 識別を行っており，センサの高感度化が必要であった。 ボールSAWデバイスを用いたセンサの高感度化に関して は, 膜塗布時の SAW 減衰増加を抑えることがポイントであ る。膜塗布後の減衰が大きくなると周回数が減るためにボー ル SAW デバイスの特長が生かせない。しかし, 均一な膜を 塗布すれば減衰量を抑えられる可能性があり, そのために $\mathrm{AC}$ エレクトロスプレイ法を検討する。また，一般に感度を 上げる為に感応膜を厚くするが, ボール SAW デバイスの場 合は膜厚が大きくなると SAW の減衰が大きくなるので最適 膜厚の検討を行う。さらに検出限界付近では雑音の低減が 有効であり, ディジタルフィルタによりその効果を調べる。 これらの手法を組み合わせて高感度化に取り組んだ結果を 報告する。

\section{2. ボール SAW デバイスの原理}

従来の板状のSAW センサでは圧電性基板表面に配置され


て SAW の励振/受信が行われる ${ }^{(7)}$ 。SAW の伝搬経路上には 感応膜が塗布されており, 匂い分子が吸着し, 質量変化や 
膜の粘弾性変化によって生じる SAW の速度変化を位相から 測定することで匂いを検出する。

一般的に, SAW の伝搬距離が長いほど精度が高くなるが, 従来のデバイスでは SAW の励振側の IDT から検出側の IDT までの距離は数 $\mathrm{mm}$ 程度であった。一方で，ボール SAW デ バイスでは発生した SAW が球表面の特定の細い経路に沿っ て非常に効率よく無回折で多数回周回する。よって, 多数 回周回させた後の弾性表面波を検出すれば, 従来のデバイ スよりもはるかに長い距離を伝搬することになり，検出さ れる SAW の遅延時間変化は大きくなる。そのため, 小型で あるにもかかわらず，従来よりも高感度のセンサ素子の実 現が期待できる。この素子の伝搬経路上に匂い分子を吸着 する感応膜を塗布することにより，匂いセンサ用センサ素 子となる。

\section{AC エレクトロスプレイ法による感応膜塗布}

〈3.1〉実 験 系本研究ではボール SAWデバイスの 高感度化を目指しているが，ボール SAW デバイスを用いる 前に水晶振動子（QCM）を用いて基礎的な検討を行うこと とした。

$\mathrm{AC}$ エレクトロスプレイ法は感応膜溶液に高電圧を印加 することで，ノズル先端から出される感応膜液滴に高電圧 を印加することで, 液滴の自発的な分裂を起こさせ微小液 滴化し, センサ上に塗布する方法である ${ }^{(8)}$ 。微小液滴の大き さが数十 $\mathrm{nm}$ となるため, 一様な膜厚による塗布が可能とな り，その結果感応膜塗布による音響損失の減少，再現性の 向上, 感度の向上が期待できる。水晶振動子の場合は電極 上に感応膜を塗布できればよいので DC エレクトロスプレ イ法でよい。しかし，ボール SAW デバイスの場合は絶縁体 上に塗布する必要があるのでこの方法は適用できず, $\mathrm{AC}$ エ レクトロスプレイ法を用いることとした。

$\mathrm{AC}$ エレクトロスプレイの実験系を図 1 に示す。シリンジ ポンプを用いて, 感応膜溶液を一定の流量でニードル先よ り押し出す。そのとき波形発生装置の波形を交流アンプを

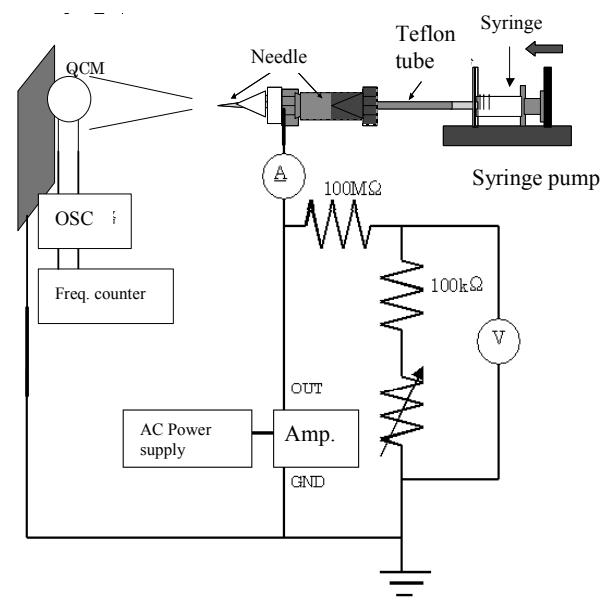

図 $1 \mathrm{AC}$ エレクトロスプレイ法実験系

Fig. 1. AC electrospray experimental setup.
用いて増幅し, ニードル先に数 $\mathrm{kV}$ 以上の高電圧を印加す る。また, 水晶振動子 ( $20 \mathrm{MHz}$, AT-cut) には発振回路を接 続し, 塗布中の発振周波数変化を周波数カウンタで計測す る。また塗布前後にネットワークアナライザで共振抵抗・ 共振周波数を測定している。

この実験系に関して塗布パラメータの最適化を行った。 ニードル先と QCM 間の距離,シリンジポンプの流量, 電源 周波数, 溶媒の種類の 4 つのパラメータについて検討した。 この中でも特に膜質に影響する, 溶媒の種類の最適化につ いて以下に述べる。

〈3·2〉最適塗布パラメータの決定 溶媒の種類をメ タノール, メタノール十水 (1: 1), アセトンに変え共振周 波数変化が約 $10 \mathrm{kHz}$ 程度になるように吸着能の高い感応膜 物質である Siponate DS-10 を塗布した時の塗布パラメータ を表 1 に示す。距離 $3 \mathrm{~cm}$, 電源周波数 $50 \mathrm{~Hz}$, 電源電圧は $12 \mathrm{kVp}-\mathrm{p}$, 流量 $0.05 \mathrm{ml} / \mathrm{h}$ である。

表 1 より, 共振抵抗変化の差はほとんどなく, どの溶媒 でも $\mathrm{Q}$ 劣化は小さいことがわかった。そこで, 実際に匂い 感度の観点から最適化を行うこととした。

フレーバの入った瓶と空の瓶を電磁弁で切り替えてセン サに引き込む匂いの濃度を制御する ${ }^{(9)}$ 。測定は室温で行っ た。これらの装置を用いて匂い感度（センサ応答 $(\mathrm{Hz}) /$ 塗布時の共振周波数変化 $(\mathrm{kHz}))$ をブタノール $(100 \% \mathrm{RC})$

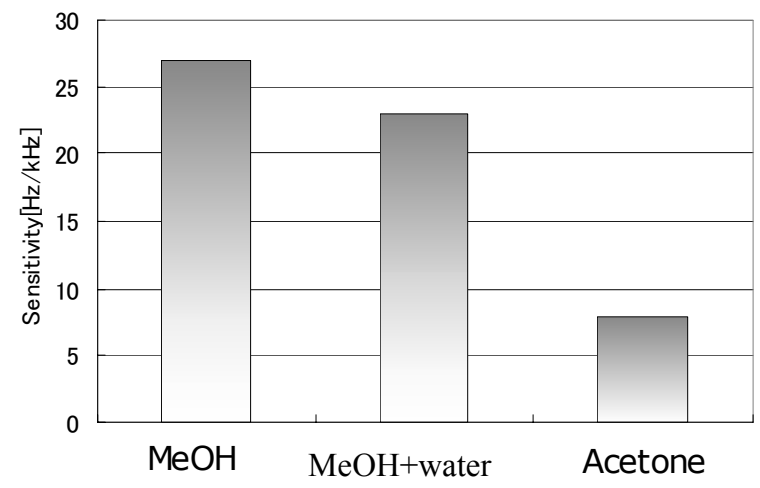

図 2 異なる感応膜溶媒を用いた時のブタノール $100 \%$ RC に対する匂い感度

Fig. 2. Sensitivity to butanol in case of different solvents.

Table 1. Parameters for coating.

\begin{tabular}{c|c|c}
\hline \hline $\begin{array}{c}\text { Solvent for } \\
\text { sensing film }\end{array}$ & $\begin{array}{c}\text { Change of resonance } \\
\text { frequency }(\mathrm{kHz})\end{array}$ & $\begin{array}{c}\text { Resistance } \\
\text { change }(\Omega)\end{array}$ \\
\hline Methanol & 10.9 & 4.7 \\
\hline Methanol+water & 10.0 & 1.2 \\
\hline Acetone & 10.9 & 4.7 \\
\hline
\end{tabular}

Table 2. Optimized parameters for coating.

\begin{tabular}{l|l}
\hline Parameter & Optimized value \\
\hline $\begin{array}{l}\text { Distance between sensor and } \\
\text { needle tip }\end{array}$ & $3 \mathrm{~cm}$ \\
\hline Flow rate of syringe pump & $0.05 \mathrm{ml} / \mathrm{h}$ \\
\hline AC frequency & $50 \mathrm{~Hz}$ \\
\hline Solvent & Methanol \\
\hline
\end{tabular}


に対して測定した結果を図 2 に示す。

溶媒をメタノールのみとしたものが他の二つの溶媒とし たものよりも感度が高くなっているので, メタノール溶媒 を選択した。

感応膜の一様性，共振抵抗変化の小ささ，匂い感度の観 点から決定した, 他の最適塗布パラメータについてもここ で表 2 にまとめる。

次節以降これらのパラメータは共通とする。

\section{AC エレクトロスプレイ法と Atomizer 法の比較}

従来から使われている感応膜塗布法に Atomizer 法があ る。これは感応膜溶液を霧状にし, その中に QCM をさらし て成膜する方法である ${ }^{(10)}$ 。ここでは，膜塗布法の違いによ る匂い感度の比較を行うために, Siponate DS-10 感応膜 $(0.5 \mathrm{mg} / \mathrm{ml})$ を AC エレクトロスプレイ法, Atomizer 法の両 塗布法で共振周波数変化が $20 \mathrm{kHz}$ 程度になるように塗布し た。表 3 に塗布結果を示す。

表 3 より共振抵抗変化の差はほとんどない。そこで, 匂 い感度から両塗布法の比較をすることとした。

匂い応答測定系を用いて図 2 と同様に，匂い物質ブタノー ル $(100 \% \mathrm{RC})$ に対するセンサの感度 $(\mathrm{Hz} / \mathrm{kHz})$ を求めた結 果を図 3 に示す。

図 3 よりエレクトロスプレイ法で塗布したセンサが 2 倍 以上感度が高くなっていることが分かる。これは $\mathrm{AC}$ エレク トロスプレイ法により Siponate DS-10 感応膜の多孔性が高 まったために, 感度が高くなったと思われる。さらに Polyphenyl ether, PEG (Polyetyleneglycol) についての感度の 比較を行ったが，これらの感応膜については Atomizer 法の 感度が高かった。しかし，エレクトロスプレイ法で塗布し た Siponate DS-10 感応膜の感度がこれら 6 個のセンサの中で 一番高かったので，次節以降この感応膜の最適化について

Table 3. Result of coating.

\begin{tabular}{c|c|c}
\hline \hline Coating method & $\begin{array}{c}\text { Change of resonance } \\
\text { frequency }(\mathrm{kHz})\end{array}$ & $\begin{array}{c}\text { Resistance change } \\
(\Omega)\end{array}$ \\
\hline AC electrospray & 21.0 & 2.9 \\
\hline Atomizer & 18.9 & 4.0 \\
\hline
\end{tabular}

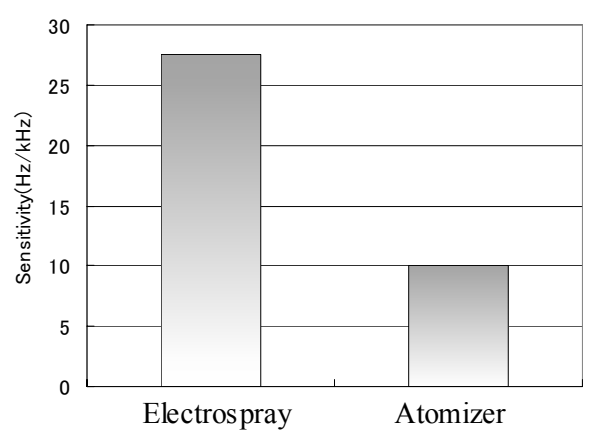

図 $3 \mathrm{AC}$ エレクトロスプレイ法と Atomizer 法の比較

$$
\text { サンプル : ブタノール }(100 \% \mathrm{RC})
$$

Fig. 3. Comparison of AC electrospray with Atomizer method.
検討する。

\section{5. 感応膜厚の最適化}

ボール SAW デバイスの感応膜厚の最適化について報告す る。一般にセンサの感応膜が厚くなると感度が高くなるが, そのかわりに SAW 減衰が大きくなり, SAW 周回数が減っ てしまうというトレードオフの関係がある。そのトレード オフの関係から, 感応膜厚の最適值があると考え最適化を 行った。

感応膜に匂い物質が吸着すると, 質量負荷効果によって デバイス表面を伝搬する SAW に遅延が生じる。その遅延を SAW の位相変化から測定する。実験系はボール SAW 実証 器を用いて ${ }^{(11)}$, 匂い調合器と組み合わせて実験を行った。 ボール SAW 実証器からセンサセル内のボール SAW デバイ スに RF バースト波を印加し, その位相出力を測定し, その データをコンピュータに送っている。位相検出法としては 直交検波（クワドラチャ検波）法を用いて SAW 位相を測定 している。測定は室温で行い, キャリアガスの流量は 2.01/min とした。キャリアガスには, 活性炭を通しフィルタ リングした室内空気を用いた。

$\mathrm{AC}$ エレクトロスプレイ法により Siponate DS-10 感応膜の 膜厚を変化させて塗布し, 安定して位相計測可能な範囲で, 出来るだけ多数回周回した SAWによる出力信号の位相を計 測した。ブタノール $(100 \% \mathrm{RC})$ を匂い物質として用い位相 変化を測定した。横軸は感応膜塗布による SAW の 6 周目の 信号の位相変化であり, 感応膜の膜厚に相当する遅延時間 変化 (感応膜厚) である。また, 縦軸を匂いに対する位相 変化としたグラフを図 4 に示す。ただし, 遅延時間変化が 70ns となったものに対しては, 塗布後に検出可能周回が 3 であったため， 3 周における SAW の遅延時間変化を二倍し て図中の遅延時間変化とした。塗布前に SAW が 90 回周回 可能だったが, 最大膜厚 (70ns) の時の最大周回数は, 先に 述べたように 3 に減少した。

図 4 より遅延時間変化が 28.9ns の時に位相変化が最大に なっており, この遅延時間変化に相当する感応膜の膜厚が

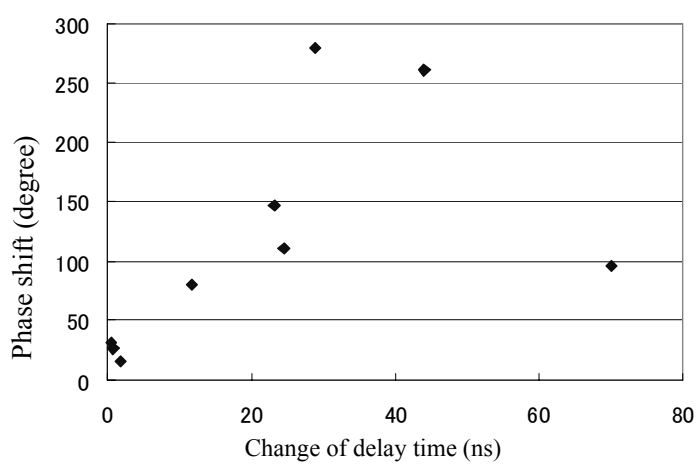

図 4 感応膜の膜厚を変えたときのブタノールに 対する位相変化

Fig. 4. Relationship between film thickness and response to butanol $(100 \% \mathrm{RC})$ at maximum rounds. 


\section{におい感度の観点から最適と言える。}

\section{6. 低濃度検出限界の検討}

最も高い感度が得られた遅延時間変化 26ns の Siponate DS-10 感応膜を塗布したボール SAW デバイスを用いて低濃 度検出限界の検討を行った。実験系を図 5 に示す。本実験 においてはサンプリングバッグ内に，匂い物質を入れ，PID (Photoionization Detector) で測定することにより低濃度サン プルの匂い濃度值を得た。

匂い物質の入ったサンプリングバッグと乾燥空気のみの 同バッグを電磁弁で切り替えることで実験を行った。匂い 物質はブタノールのみとし，濃度は 90ppb，40ppbに設定し た。60-120s，180-240s の間に匂い物質を供給しそれ以外は

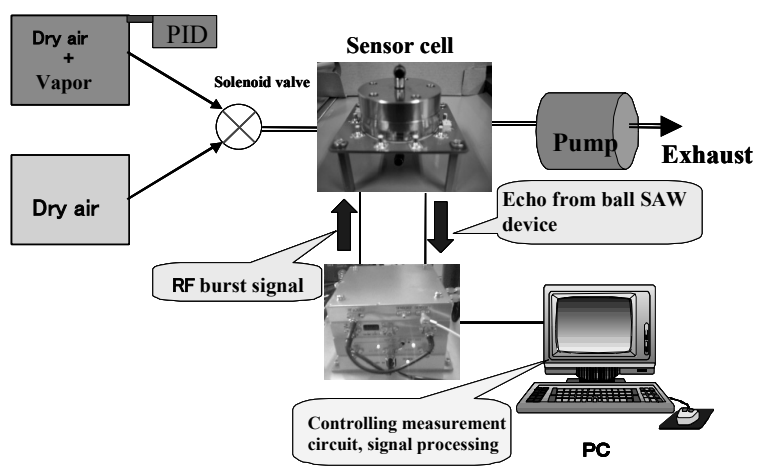

図 5 低濃度匂い応答測定系

Fig. 5. Experimental setup for low concentration odor.

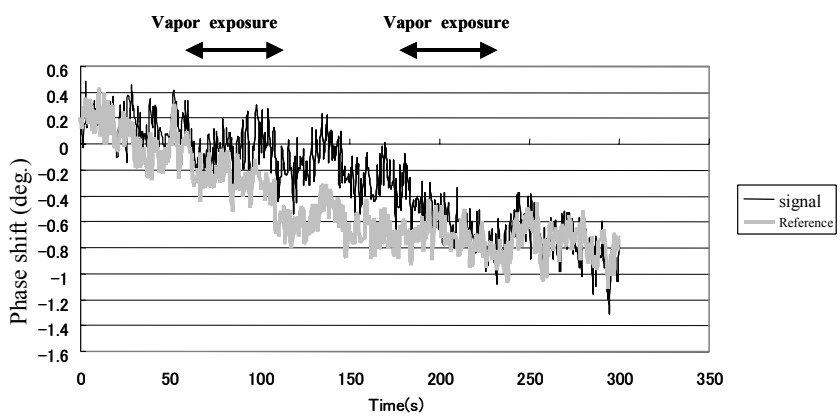

図 $640 \mathrm{ppb}$ のブタノールに対する位相変化 Fig. 6. Sensor response to butanol (40ppb).

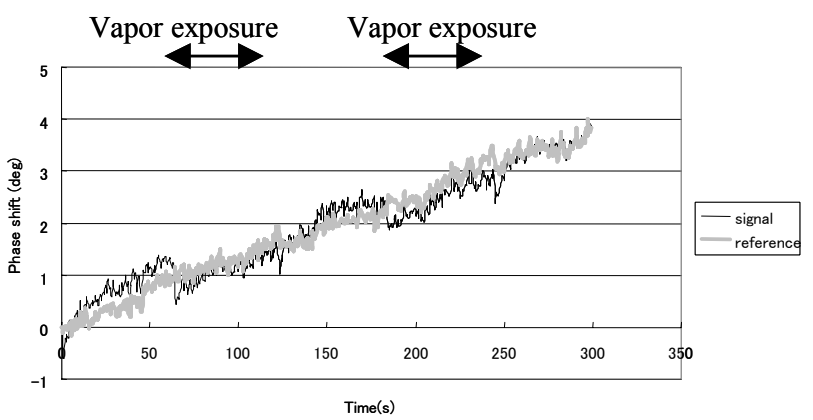

図 $790 \mathrm{ppb}$ のブタノールに対する位相変化

Fig. 7. Sensor response to butanol (90ppb).
乾燥空気とした。後に温度補償を行うために, 感応膜を塗 布していないボール SAWデバイスを参照デバイスとして同 時に位相測定した。それらの測定結果を図 6,7 に示す。

図 6, 図 7 より, 温度ドリフトが存在しどちらも匂い忘答 部が判然としていない。そこで，まず温度補償のために信 号用の応答から参照用の応答の差分を計算した。さらにピ 一クの先鋭化を行い, ノイズを抑え, さらに残存温度ドリ フトを除去するため Savitzky-Golay フィルタによる平滑化 と微分処理を組み合わせた処理を行った ${ }^{(12)}$ 。その概念図を 図 8 に示す。

空内データに対して多項式近似によるスムージングを行 い，その近似多項式を微分し，中央の值をY に変える。そ の処理を空を移動しながら繰り返す。原データを平滑化後

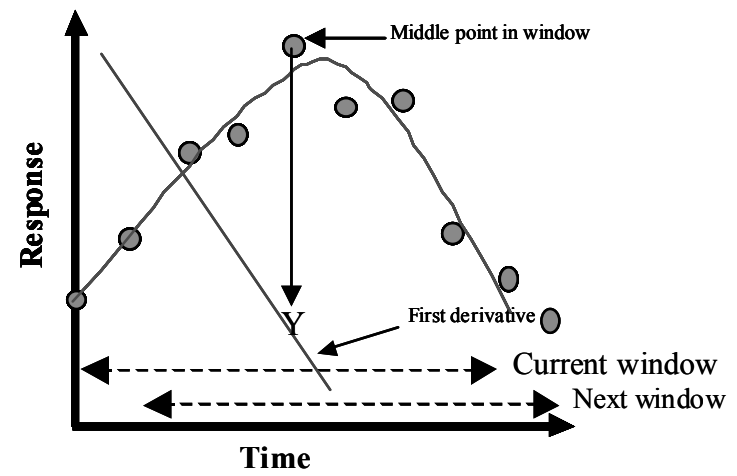

図 8 Savitzky-Golay フィルタ概念図

Fig. 8. Savitzky-Golay filter.

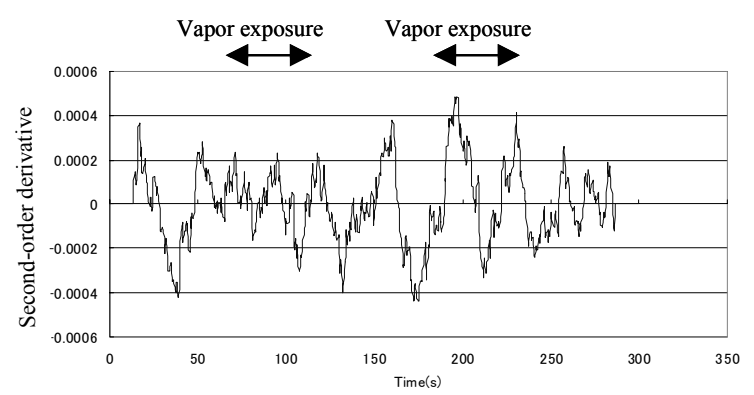

図 9 補正後の $40 \mathrm{ppb}$ ブタノール応答波形

Fig. 9. Waveforms of response to $40 \mathrm{ppb}$ butanol after compensation.



図 10 補正後の $90 \mathrm{ppb}$ ブタノール応答波形

Fig. 10. Waveforms of response to $90 \mathrm{ppb}$ butanol after compensation. 
に微分するのではなく, 平滑化で得られた近似多項式を微 分して空内中央の時間の微分值を得る。平滑化と同時に微 分処理を行うことで，ノイズの影響を極力減らした上で, 差分計算により取り除くことができなかった残存温度ドリ フトを除去し，ピークの先鋭化を行う。

図 6, 図 7 の波形に対して差分による温度補償後, 平滑化 と微分処理を適用した。フィルタの空幅は 28.5 秒, 近似次 数 3 に設定し二階微分処理した。結果を図 9, 10 に示す。

図 9 に示すように, $40 \mathrm{ppb}$ の濃度では応答はノイズに埋も れており匂い応答を検出する事が出来なかった。しかし， 図 10 の 90ppb のブタノールに関しては，温度ドリフトが取 り除かれており, さらに微分法の効果からピークが先鋭化 されるのと同時にノイズの拡大も抑えられており SN 比が 高くなっている。匂い応答部のピークの值もほぼ等しくなっ ており，再現性の高い測定がこの補正によってできる可能 性がある。また，400ppb, 2ppm の濃度に関しても測定を行 い濃度と共にセンサ応答が増大することは確認した。

\section{7. ボール SAW デバイスと水晶振動子の比較}

最後に, ボール SAW デバイスと水晶振動子の性能比較を 行うこととした。比較対象の水晶振動子は本研究室でもつ とも感度の高いもので, 感応膜は Siponate DS-10, 塗布時の 共振周波数変化は $60 \mathrm{kHz}$ ，Atomizer 法によって狳布した。 ボール SAW デバイスは前述のように膜塗布により周回数 6 の場合に 26ns シフトしたセンサを用いている。この膜厚は 文献 13 に示した換算式により $20 \mathrm{MHz}$ の水晶振動子の場合 $5.98 \mathrm{kHz}$ の周波数シフトに相当する。感度の比較のために, 図 11 , 図 12 に 40ppb,90ppb のブタノールに対する匂い态答 測定結果を示す。図 6，7 のボール SAW デバイスのデータ （温度補正後）と同時に測定した QCM のデータを加えて示 した。水晶振動子のセンサセルを図 5 において, ボール SAW センサセルと直列に接続して測定を行った。ただし周波数 変化は見やすくするため正負を逆にしている。

これら二つの図から，40ppbについては，どちらも匂い応 答が測定が困難なのに対し，90ppbのブタノールについては どちらも検出できている。これより両センサとも 90ppb 程 度が検出限界であり, 両センサは感度がほぼ同等と言える。 なお，ブタノールに対する人間の嗅覚閾值は $490 \mathrm{ppb}$ 程度で あり ${ }^{(7)}$, 嗅覚閾值以下の濃度の匂いを検出することに成功し た。

次にセンサ応答速度について比較する。匂いサンプルは 900ppm のブタノールを用いた。グラフを図 13 に示す。比 較のため応答の最大值を一致させる規格化を行った。

図 13 より, グラフから匂い応答が飽和するまでにボール SAW デバイスが約 10 秒なのに対し, QCM は約 60 秒かかっ ており, センサ応答速度はボール SAW が数倍速くなってい ることがわかる。

以上まとめると両センサは感度同等であり，センサ応答 速度はボール SAW デバイスが数倍速いということである。 このセンサ応答が速い理由としては, 感応膜厚がうすいこ

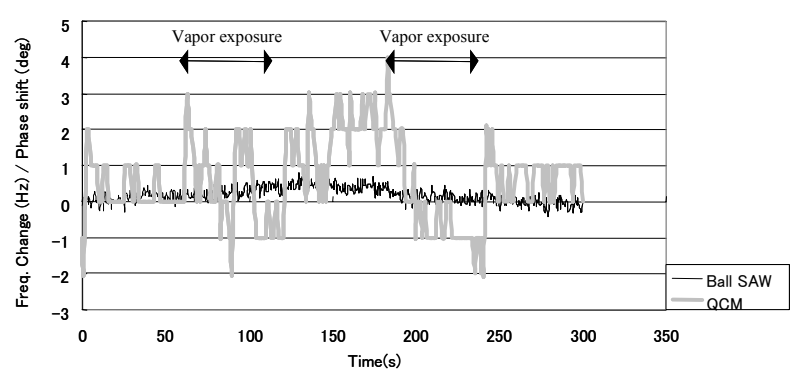

図 11 ボール SAW と QCM の応答比較 $(40 \mathrm{ppb})$ Fig. 11. Comparison of ball SAW device with QCM (40ppb butanol).

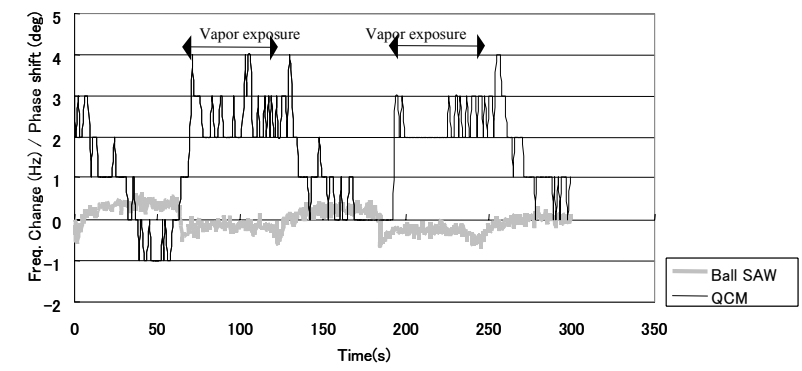

図 12 ボール SAW と QCM の応答比較 (90ppb) Fig. 12. Comparison of ball SAW device with QCM (90ppb butanol).

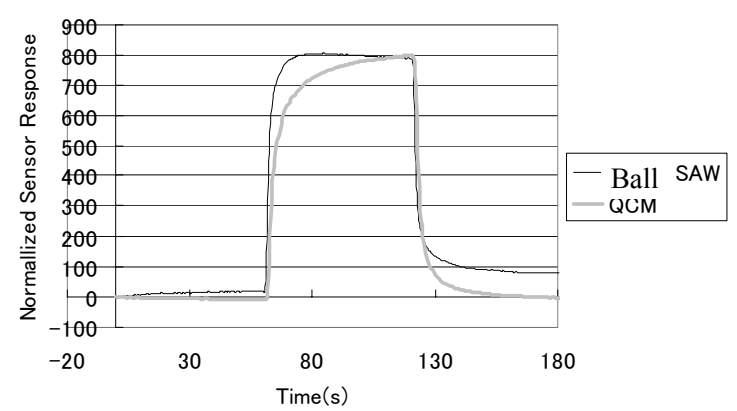

図 13 ボール SAW と QCM の応答速度比較

Fig. 13. Comparison of ball SAW with QCM sensor response speed (Sample: butanol 900ppm).

と（水晶振動子の約 1/10）があげられる。

QCM の膜厚をボール SAW デバイスと同じにすると応答 速度はボール SAW デバイスと同程度が期待できるが, 感度 が低下し，感度と応答速度を両立できない。

\section{8. 結 論}

本研究はボール SAW デバイスを用いて, 匂い感度向上を 目的として行った。まず, 水晶振動子を用いた基礎検討に おいては, 感応膜の塗布法の一つである ACエレクトロスプ レイ法の塗布パラメータの最適化した。さらに, ボール SAW デバイスの感応膜厚を匂い感度最大化の観点から最適化に 成功することができた。そして, 最適膜厚のボール SAW デ バイスを用いて低濃度検出限界の検討を行い, さまざまな 
信号処理を適用することで 90ppb のブタノールの検出に成 功した。最後に, 最高感度の水晶振動子とボール SAW デバ イスの比較を行い, 感度同等でセンサ応答速度が数倍とい う優れたセンサ機能を持つことを立証することができた。 ボール SAW デバイスは今後, 結晶球材料や感応膜の形成方 法，駆動方法の改良によって高感度化する余地が多く残さ れている。有機感応膜材料を使えると共に，消費電力が非 常に小さく集積化が容易である特徴は匂いセンサに適した デバイスであり, 特に応答速度の要求される分野で用途展 開が期待される。

本研究ではブタノールを中心に研究したが, 同じ炭素数 の酸ではさらに感度が高く, アルデヒドではアルコールよ り感度が低かった。選択性を得るためには異なる感応膜を 塗布したセンサアレイを構成する必要があり，今後低濃度 で匂い識別実験を行いたい。

(平成 20 年 3 月 26 日受付，平成 20 年 6 月 14 日再受付)

\section{文献}

（1）中本高道, 「食品感性工学」, 相良監修, 農林水産技術情報協会, pp.129-168 (2004)

(2) N. Nakaso, Y. Tsukahara, S. Ishikawa, and K. Yamanaka : Proc. 2002 IEEE Ultrason. Symp., Vol.47 (2002)

( 3 ) K. Yamanaka, H. Cho, and Y. Tsukahara : Appl. Phys. Lett., Vol.76, p.2797 (2000)

(4) Y. Tsukahara, N. Nakaso, H. Cho, and K. Yamanaka : Appl. Phys. Lett., Vol.77, p.2926 (2000)

(5) K. Yamanaka, S. Ishikawa, N. Nakaso, N. Takeda, D. Y. Sim, T. Mihara, A. Mizukami, I. Satoh, S. Akao, and Y. Tsukahara : IEEE Trans. UFFC, Vol.53, p.793 (2006) IEEE Trans. UFFC, Vol.53, p.793 (2006)

(6) T. Nakamoto, K. Aoki, T. Ogi, S. Akao, and N. Nakaso : Sens \& Actuators B, Vol.130, p.386 (2008)

(7) A. Snow and H. Wohltjen : Anal. Chem, Vol.56, pp.1411-1416 (1984)

(8) S. Sarkar, N. Levit, and G. Tepper : Sens \& Actuators B, Vol.114, p.756 (2006)

(9) T. Yamanaka, R. Matsumoto, and T. Nakamoto : Sens \& Actuators B, Vol.87, p.457 (2002)

(10) S. Munoz, T. Nakamoto, and T.Moriizumi : Sens \& Actuators B, Vol.1105, p. $105(2005)$

(11) T. Abe, N. Iwata, T. Tsuji, T. Mihara, S. Akao, K. Noguchi, N. Nakaso, D. Sim, Y. Ebi, T. Fukiura, H. Tanaka, and K. Yamanaka : Jpn. J. Appl. Phys., Vol.46, pp.4726-4728 (2007)

(12) K. R. Beebe, R. J. Pell, and M. B. Sensholiz : John Wiley \& Sons, Chemometrics Practical guide, p.348 (1998)

（13）青木健治 - 中本高道 - 大木恒郎 - 赤尾慎吾 - 中務玩也：信学技報, US2005-84 (2005)

（学生員） 1973 年 11 月 23 日生。 2006 年 3 月 東京工業大学卒業。現在同大学修士課程にて, 匂いセンサの研究に従事。

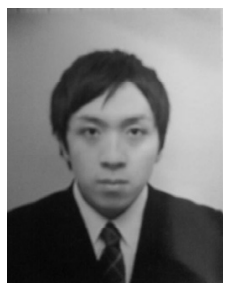

Bartosz Wyszynski（非会員） 1974 年 5 月 31 日生。 2001 年 11 月

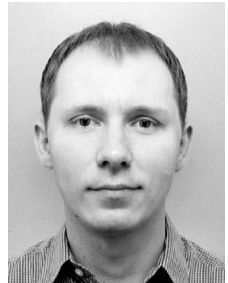
Technical University of Szcecin 博士課程修了。現 在, 東京工業大学産学官連携研究員。匂いセン サの感応膜研究に従事。2005-2007 年日本学術 振興会外国人特別研究員。

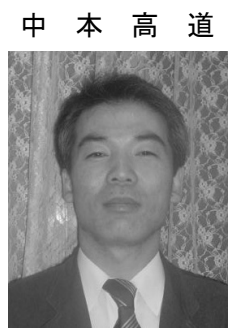

（正員） 1982 年東京工業大学電気電子工学科 卒業。1984 年同大学院電気電子工学専攻修士課 程修了。同年日立製作所（株）入社。1987 年東 京工業大学助手。1993 年同大助教授となり現在 同大准教授。工学博士。1996-1997, 米国パシ フィックノースウェスト研究所客員研究員。匂 いセンサ，ニューラルネットワーク，センサ情 報処理用 ASIC の研究に従事。

中 曽 教 尊

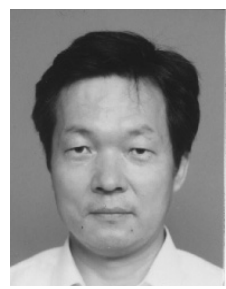

野 口 和 洋



（非会員） 1985 年広島大学卒業。1995 年東北 大博士課程修了。1985 年に凸版印刷（株）に入 社し現在同社課長。2000 年よりボール SAW デ バイスの研究に従事。1989 年 Outstanding Paper Award of IEEE Transaction on Ultrasonics, Ferroelectronics and Frequency control を受賞。 2000 年日本非破壊検查学会 Best paper award 受 賞。

(非会員) 1969 年 1 月生。1992 年 3 月宇都宮 大学卒業。1994 年 3 月同大修士課程修了。同年 凸版印刷（株）入社。現在, ボール SAW デバ イスの研究に従事。 